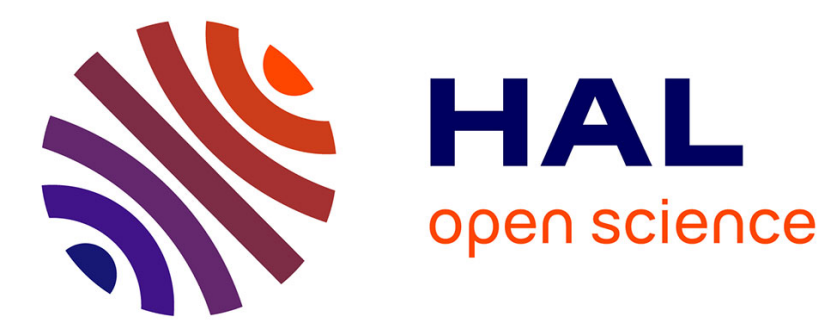

\title{
High-Temperature Solar Methane Dissociation in a Multitubular Cavity-Type Reactor in the Temperature Range 1823-2073 K
}

Sylvain Rodat, Stéphane Abanades, Gilles Flamant

\section{- To cite this version:}

Sylvain Rodat, Stéphane Abanades, Gilles Flamant. High-Temperature Solar Methane Dissociation in a Multitubular Cavity-Type Reactor in the Temperature Range 1823-2073 K. Sustainable Energy \& Fuels, 2009, 23 (5), pp.2666-2674. 10.1021/ef900037v . hal-02571379

\section{HAL Id: hal-02571379 \\ https://hal.science/hal-02571379}

Submitted on 12 May 2020

HAL is a multi-disciplinary open access archive for the deposit and dissemination of scientific research documents, whether they are published or not. The documents may come from teaching and research institutions in France or abroad, or from public or private research centers.
L'archive ouverte pluridisciplinaire HAL, est destinée au dépôt et à la diffusion de documents scientifiques de niveau recherche, publiés ou non, émanant des établissements d'enseignement et de recherche français ou étrangers, des laboratoires publics ou privés. 


\title{
High-temperature solar methane dissociation in a multi- tubular cavity-type reactor in the temperature range $1823-2073 \mathrm{~K}$
}

\author{
Sylvain RODAT*, Stéphane ABANADES, Gilles FLAMANT \\ Processes, Materials, and Solar Energy Laboratory, CNRS (PROMES-CNRS, UPR 8521), 7 Rue du \\ Four Solaire, 66120 Odeillo Font-Romeu, France
}

\begin{abstract}
Methane cracking is a possible route for the co-production of hydrogen and carbon black avoiding $\mathrm{CO}_{2}$ emission. An indirect heating solar reactor prototype, allowing thermal dissociation of methane without catalyst, is tested at high temperatures. It is composed of a cubic graphite cavity receiver (20 cm side) equipped with four independent vertical tubular reaction zones. The concentrated solar radiation (2-4 MW/m²) is absorbed through an hemispherical quartz window by a $9 \mathrm{~cm}$-diameter aperture. A set of experimental results on solar methane dissociation is presented for the temperature range 1823-2073 K. The effects of temperature, residence time from $10 \mathrm{~ms}$ and beyond $100 \mathrm{~ms}$, gas flow-rates up to $12 \mathrm{NL} / \mathrm{min}\left(2 \times 10^{-4} \mathrm{Nm}^{3} \mathrm{~s}^{-1}\right)$ of methane, and methane concentration up to $100 \%$ are investigated. Moreover, an experimental run was also carried out with natural gas instead of pure methane. Typical hydrogen and carbon mass balances show that methane is efficiently converted into hydrogen whereas it is not as well converted into solid carbon due to the production of acetylene. A twostep mechanism for methane dissociation is presented in order to define accurately the reactor efficiencies (thermal efficiency and solar-to-hydrogen thermo-chemical conversion).
\end{abstract}

\footnotetext{
* Corresponding author. Fax: +33468302940.

E-mail address: sylvain.rodat@promes.cnrs.fr .
} 
Keywords: Hydrogen production; Concentrated solar energy; Methane dissociation; Solar reactor; Natural gas; Carbon black. 


\section{1-Introduction}

In order to counter the rising $\mathrm{CO}_{2}$ emissions, the decarbonisation of energy is required and hydrogen appears as the most promising energy carrier. Natural gas (mainly composed of methane) may play a major role on the way toward a carbon free energy ${ }^{1}$. It is the cleanest hydrocarbon fuel and it can benefit from transportation infrastructures. Nowadays, hydrogen is mainly produced from steam methane reforming $^{2}$, while carbon black is principally produced from the furnace process ${ }^{3}$. Both processes release large amounts of $\mathrm{CO}_{2}$ in the atmosphere. Solar thermal methane cracking could be a solution for the clean co-production of hydrogen and carbon black. About $92 \%$ of the pollution associated with the two conventional processes is eliminated ${ }^{4}$. The overall reaction can be written as:

\section{$\mathrm{CH}_{4} \rightarrow 2 \mathrm{H}_{2}+\mathrm{C}$}

(1)

$\Delta \mathrm{H}^{\circ}=75 \mathrm{~kJ} \mathrm{~mol}^{-1}\left(216 \mathrm{~kJ} \mathrm{~mol}^{-1}\right.$ for $\mathrm{CH}_{4}$ at $298 \mathrm{~K}$ and products at $\left.2000 \mathrm{~K}\right)$.

The reaction is endothermal and solar thermal energy is used as power input, which results in the absence of $\mathrm{CO}_{2}$ release in the process. At thermodynamic equilibrium, the dissociation is complete for temperatures beyond $1500 \mathrm{~K}^{5}$. Nevertheless, Holmen et al. ${ }^{6}$ point out the presence of products such as $\mathrm{C}_{2} \mathrm{H}_{6}, \mathrm{C}_{2} \mathrm{H}_{4}$, and $\mathrm{C}_{2} \mathrm{H}_{2}$ depending on the residence time. These species are the ones involved in the commonly accepted dehydrogenation of methane ${ }^{7}$. Thermodynamic equilibrium is not reached due to kinetic limitations. The overall decomposition of methane has been studied by investigating either a catalytic or a non-catalytic reaction. For non-catalytic reaction, activation energies range between 312 $\mathrm{kJ} / \mathrm{mol}^{8}$ and $451 \mathrm{~kJ} / \mathrm{mol}^{9}$, whereas activation energies are lower $\left(143 \mathrm{~kJ} / \mathrm{mol}^{10}-236 \mathrm{~kJ} / \mathrm{mol}^{11}\right)$ for the catalytic decomposition reaction.

In previous works on methane cracking, Lédé et al. ${ }^{12}$ mentioned in 1978 the use of a solar reactor to apply thermal shocks to methane. A complete bibliographic survey on methane pyrolysis after 1960 was published by Billaud et al. ${ }^{13}$. Solar thermal cracking of methane also enabled the production of nanotubes ${ }^{14}$. Special interest was given to solar methane cracking for the co-production of hydrogen and 
carbon black during the last five years. Two possible reactor designs were investigated, the direct ${ }^{15-19}$ and the indirect heating concepts ${ }^{2,4,20}$. In the latter configuration, the solar irradiated zone is separated from the reacting flow whereas in the former, no separation is used, and particles seeding is required for efficient gas heating.

This work reports on the results obtained with a novel prototype-scale solar reactor (mean power: 20 $\mathrm{kW}$ ) featuring a cubic graphite cavity (behaving as a black-body cavity) with four vertical inside tubular reaction zones. This design enables the control of the reactor tube temperature and is also suitable for scaling-up. Previous results on low temperature runs (in the range 1670-1770 K) have already been reported and have permitted to validate the Dsmoke kinetic code for the chemical reaction modelling applied to methane decomposition ${ }^{21}$. It also showed that increasing the temperature favour the methane conversion. Therefore, a second series of experiments at higher temperatures was performed in the range 1823-2073 K and the noteworthy results are discussed in the following sections.

\section{2- Experimental Section}

\section{1-Design of the reactor}

The reactor is presented in Fig. 1. It is composed of a graphite cavity receiver of cubic shape. Its side is $20 \mathrm{~cm}$ long and the aperture diameter is $9 \mathrm{~cm}$. The reactor was designed for a nominal power in the range $15-25 \mathrm{~kW}$. Inside the cavity, four independent and identical tubular reaction zones are positioned vertically and work in parallel. Each reaction zone is composed of two concentric tubes (Fig. 2). This design warrants a pre-heating of the feed gas by the hot products. The innermost tube is $4 \mathrm{~mm}$ i.d. and $12 \mathrm{~mm}$ o.d., while the outer tube is $18 \mathrm{~mm}$ i.d. and $24 \mathrm{~mm}$ o.d.. A mixture of methane and argon is fed in the innermost tube and the products flow out through the annular space between the two tubes. The total tube length is $380 \mathrm{~mm}: 178 \mathrm{~mm}$ are heated in the graphite cavity directly exposed to solar irradiation, while the remaining length goes through the insulating layers. Three different insulating 
layers surround the graphite cavity in order to limit conduction losses. They form an insulation layer of $0.15 \mathrm{~m}$ thickness $(0.05 \mathrm{~m}$ for each insulating material). The 3 insulating materials are a graphite felt in contact with the cavity $\left(\lambda=0.53 \mathrm{~W} \cdot \mathrm{m}^{-1} \cdot \mathrm{K}^{-1}\right.$ at $\left.1873 \mathrm{~K}\right)$, an intermediate refractory ceramic fiber operating up to $1873 \mathrm{~K}\left(62 \% \mathrm{Al}_{2} \mathrm{O}_{3}, 30 \% \mathrm{SiO}_{2}, \lambda=0.35 \mathrm{~W} \cdot \mathrm{m}^{-1} \cdot \mathrm{K}^{-1}\right.$ at $\left.1673 \mathrm{~K}\right)$, and an outer microporous insulator operating up to $1273 \mathrm{~K}\left(20 \% \mathrm{ZrO}_{2}, 77.5 \% \mathrm{SiO}_{2}, 2.5 \% \mathrm{CaO}, \lambda=0.044 \mathrm{~W} \cdot \mathrm{m}^{-1} \cdot \mathrm{K}^{-1}\right.$ at $\left.1073 \mathrm{~K}\right)$. The reactor shell $(535 \times 535 \times 373 \mathrm{~mm})$ is made of stainless steel. As far as the front face is concerned, it is aluminummade with water-cooling channels. A water-cooled copper-made component enables to hold the hemispherical quartz window. This transparent window closes the cavity, which helps to create an inert atmosphere. It prevents the graphite from oxidizing since the graphite cavity is swept by a nitrogen flow. Both the direct concentrated solar radiations from the sun and the IR radiations from the cavity walls contribute to the tubes heating. The solar concentrating system used is the $1 \mathrm{MW}$ solar furnace of the CNRS-PROMES laboratory. It is composed of a field of 63 sun-tracking heliostats (45 $\mathrm{m}^{2}$ each) and a parabolic concentrator $\left(1830 \mathrm{~m}^{2}\right)$ delivering up to 9000 suns at the focal point. For the experiments at 15-25 kW scale, only a limited number of heliostats (25) was used along with a shutter to control the incoming flux density in the range $2-4 \mathrm{MW} / \mathrm{m}^{2}$. Then, the reactor aperture $(9 \mathrm{~cm}$-diameter $)$ determined the absorbed solar power. 


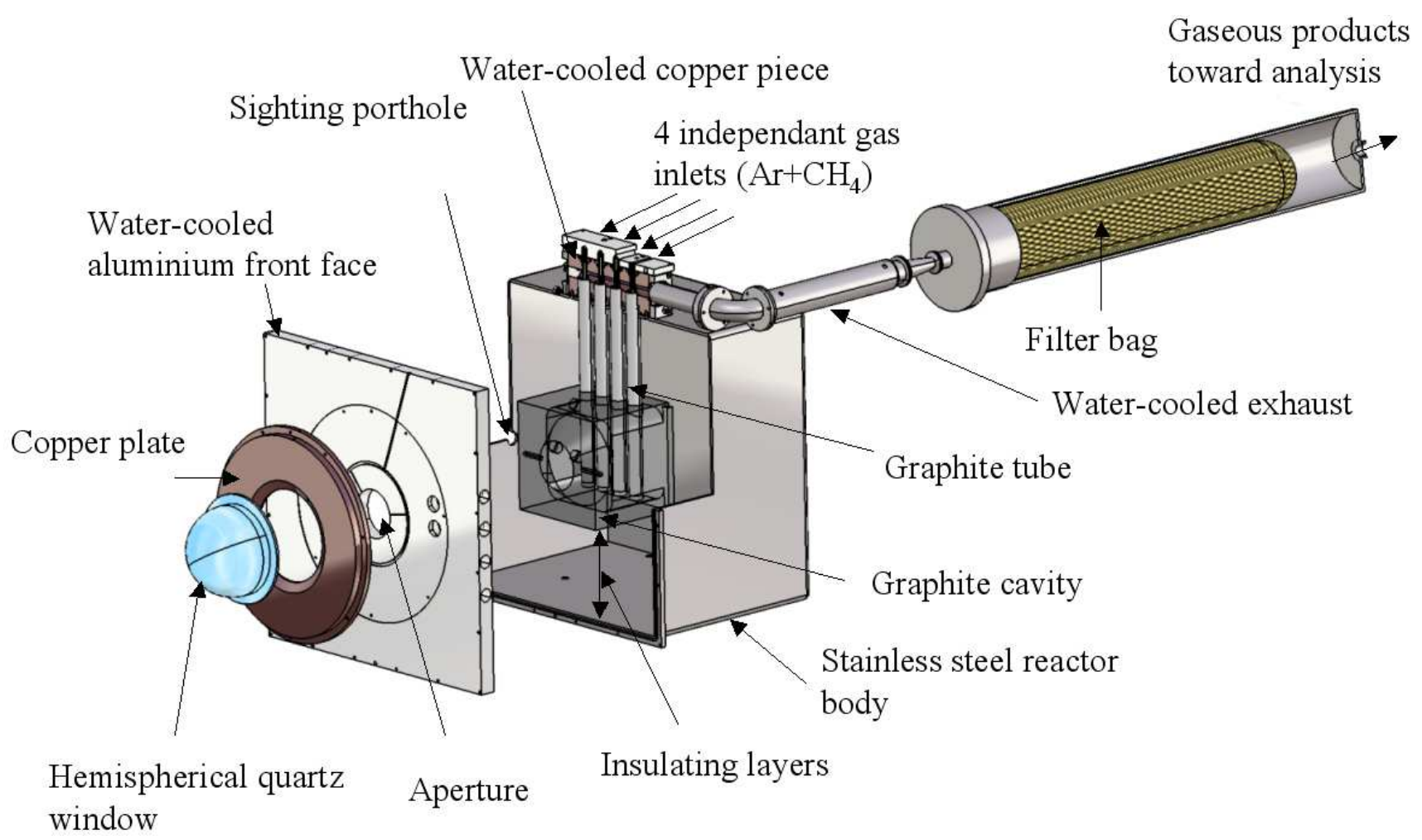

Figure 1. Scheme of the prototype-scale solar reactor and filter

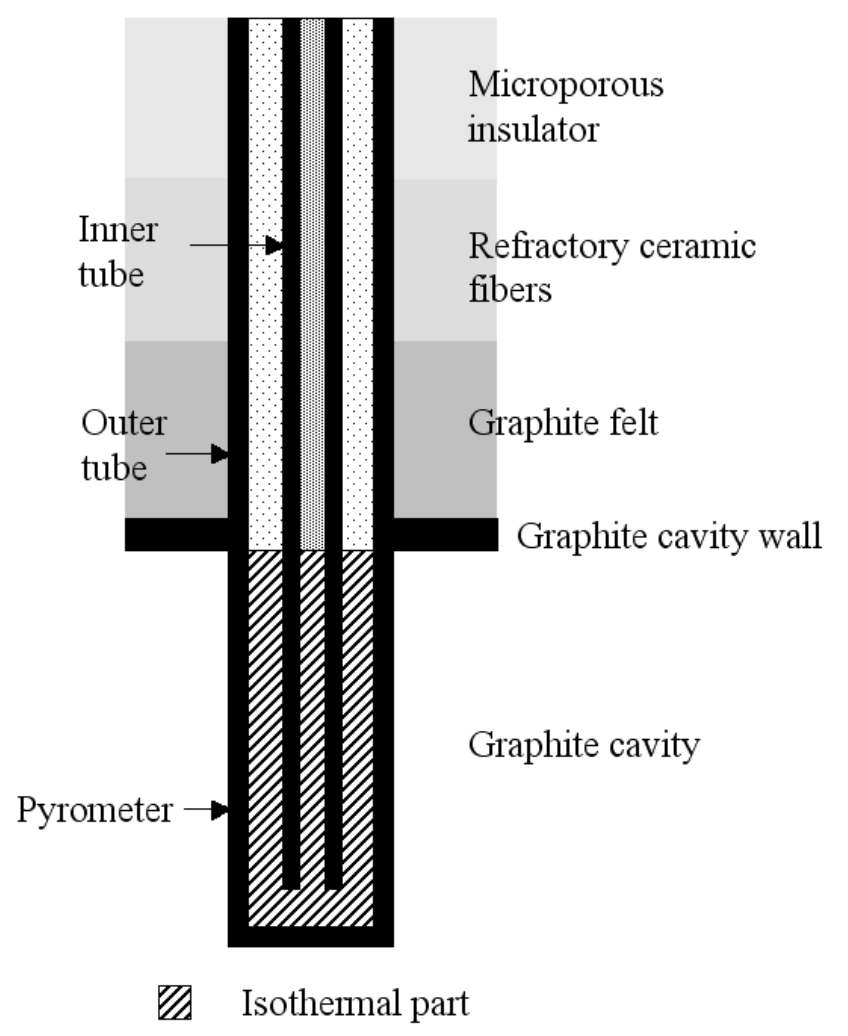

Figure 2. Scheme of the concentric tubes 


\section{2-Experimental procedure}

Each experiment starts with a heating period (about $30 \mathrm{~min}$ ) with an argon flow in the tubes in order to reach the targeted temperature. Temperature is controlled thanks to a solar-blind optical pyrometer (wavelength: $5.14 \mu \mathrm{m}$ ) pointing toward a tube wall through a $\mathrm{CaF}_{2}$ window. A type $\mathrm{B}$ thermocouple (Pt$\mathrm{Rh}$ ) is placed in contact with the graphite cavity but has to be removed for temperatures above $1973 \mathrm{~K}$ (maximal working temperature for this device). Once the desired temperature is reached, a controlled mixture of argon and methane can be injected. This is enabled thanks to 8 mass-flow controllers (4 for methane and 4 for argon). Two mass-flow controllers are dedicated to each tube (Brooks Instruments model $5850 \mathrm{~S}$, precision $0.7 \%$ of the measurement $+/-0.2 \%$ of the full scale, range $0-10 \mathrm{NL} / \mathrm{min}(0-$ $\left.1.67 \times 10^{-4} \mathrm{Nm}^{3} \mathrm{~s}^{-1}\right)$ for methane and 0-20 NL/min $\left(0-3.33 \times 10^{-4} \mathrm{Nm}^{3} \mathrm{~s}^{-1}\right)$ for argon, where NL means Normal Liter that corresponds to one liter at normal conditions (101,325 Pa, 273.15 K)). There is no gas pre-heating before entering the reactor tubes since the gases are fed through a water-cooled copper component at the top of the reactor (Fig. 1). When leaving the reactor tubes, the gas products are collected in this same water-cooled copper component that allows the cooling of products below $373 \mathrm{~K}$. Then, the gases flow in a water-cooled pipe before entering a solid-gas separation unit. Accordingly, the products flow through a filter bag (diameter: $127 \mathrm{~mm}$, length: $800 \mathrm{~mm}$ ) to separate carbon particles. It is made of Ryton with a Mikrotex membrane (type $3601-57,500 \mathrm{~g} / \mathrm{m}^{2}$ ). Then, a bypass stream to be analyzed is aspired through a set including a primary sampling pump that feeds a continuous analyzer and a secondary sampler (peristaltic pump) that feeds a gas chromatograph (GC, Varian CP 4900). The GC is equipped with 2 channels (the retention times are reported after each relevant species): channel 1 (MolSieve 5A PLOT 10M) for $\mathrm{H}_{2}(25 \mathrm{~s}), \mathrm{CH}_{4}(41 \mathrm{~s})$; channel 2 (PoraPLOT U 10M) for hydrocarbons such as $\mathrm{CH}_{4}(22 \mathrm{~s}), \mathrm{C}_{2} \mathrm{H}_{6}(43 \mathrm{~s}), \mathrm{C}_{2} \mathrm{H}_{4}(37 \mathrm{~s}), \mathrm{C}_{2} \mathrm{H}_{2}(54 \mathrm{~s})$, and $\mathrm{H}_{2}(21 \mathrm{~s})$. The carrier gas used for chromatography analysis is argon, also used as buffer gas during methane cracking experiments, thereby eliminating the matrix effects. Continuous analysis of methane and hydrogen is enabled by a specifically 
devoted multi-component gas analyser (Rosemount NGA 2000 MLT3, resolution: 1\% of the full scale), and the methods used for $\mathrm{H}_{2}$ and $\mathrm{CH}_{4}$ analysis are thermal conductivity and non-dispersive infrared detections, respectively. The measurement of $\mathrm{CH}_{4}$ concentration is used for interference crosscompensation in the measurement of $\mathrm{H}_{2}$. The operation under reduced pressure (about $40 \mathrm{kPa}$ ) is enabled thanks to the use of a venturi vacuum pump (P6010 SI32-3X4, feed pressure $400 \mathrm{kPa}$, maximum vacuum flow of $3.2 \mathrm{NL} / \mathrm{s}\left(5.33 \times 10^{-5} \mathrm{Nm}^{3} \mathrm{~s}^{-1}\right)$ at $\left.-40 \mathrm{kPa}\right)$. In order to monitor the pressure in each tube, absolute pressure transmitters with ceramic cells equip each tube entrance. The measurement scale is $0-400 \mathrm{kPa}$ and the precision is $+/-0.30 \%$ of the full scale.

\section{3-Experimental conditions}

The investigated temperature range is $1823-2073 \mathrm{~K}$. Temperature was proved to be homogeneous in the graphite cavity according to numerical simulations ${ }^{22}$. They also confirmed that the gas temperature has reached the wall temperature at the pyrometer position (Fig. 2). The methane mole fraction varies between $10 \%$ and $100 \%$ with a total methane flow-rate ranging between $0.8 \mathrm{NL} / \mathrm{min}$ and $12 \mathrm{NL} / \mathrm{min}$ $\left(1.33 \times 10^{-5}\right.$ and $\left.2 \times 10^{-4} \mathrm{Nm}^{3} \mathrm{~s}^{-1}\right)$. The absolute pressure is about $40 \mathrm{kPa}$ inside the tubes. The flow is laminar (Reynolds number < 2000). The typical mean duration of an experimental run at a given temperature is 45 min before tube blocking (due to carbon accumulation), and it depends strongly on the experimental conditions (dilution ratio, methane flow-rate and conversion). The pre-heating period is about half an hour.

\section{3-Results and Discussion}

For each experimental condition, various parameters are calculated:

- The residence time $\tau$ of the gas species is calculated by dividing the volume of the isothermal part of the tube (part inserted in the graphite cavity, Fig. 2) by the volumetric inlet flow-rate of 
argon and methane at the real tube temperature and pressure. It is often referred as "space time" ${ }^{, 23}$. It permits to give a characteristic reaction time even if chemical expansion is not included. In the following discussion, "residence time" will always refer to this definition.

$\tau=\frac{\mathrm{V}_{\mathrm{r}}}{\mathrm{Q}_{0}}$

- The $\mathrm{CH}_{4}$ conversion gives the proportion of methane that has been transformed and it is defined as:

$$
\mathrm{X}_{\mathrm{CH}_{4}}=\frac{\mathrm{F}_{0}, \mathrm{CH}_{4}-\mathrm{F} \cdot \mathrm{yCH}_{4}}{\mathrm{~F}, \mathrm{CH}_{4}}
$$

- The $\mathrm{H}_{2}$ yield is the proportion of methane that has been converted into hydrogen and it is calculated from:

$$
\mathrm{Y}_{2}=\frac{\mathrm{F} \cdot \mathrm{yH}_{2}}{2 \cdot \mathrm{F}_{0}, \mathrm{CH}_{4}}
$$

- The $\mathrm{C}$ yield is the proportion of methane that has been converted into solid carbon and it is expressed as:

$$
\mathrm{Y}_{\mathrm{C}}=\frac{\mathrm{F}_{0}, \mathrm{CH}_{4}-\left(\mathrm{F} \cdot \mathrm{yCH}_{4}+2 \cdot \mathrm{F} \cdot \mathrm{yC}_{2} \mathrm{H}_{2}+2 \cdot \mathrm{F}_{2} \mathrm{yC}_{2} \mathrm{H}_{4}+2 \cdot \mathrm{F} \cdot \mathrm{yC}_{2} \mathrm{H}_{6}\right)}{\mathrm{F}_{0}, \mathrm{CH}_{4}}
$$

where $\mathrm{F}_{0, \mathrm{CH}}$ is the inlet molar flow-rate of $\mathrm{CH}_{4}, \mathrm{y}_{\mathrm{i}}$ is the mole fraction of species $\mathrm{i}$, and $\mathrm{F}$ is the total outlet flow-rate (including argon as buffer gas) obtained from:

$\mathrm{F}=\mathrm{F}_{\mathrm{Ar}}+\mathrm{F} \cdot \mathrm{yCH}_{4}+\mathrm{F} \cdot \mathrm{yH}_{2}+\mathrm{F} \cdot \mathrm{yC}_{2} \mathrm{H}_{2}+\mathrm{F} \cdot \mathrm{yC}_{2} \mathrm{H}_{4}+\mathrm{F} \cdot \mathrm{yC}_{2} \mathrm{H}_{6}$

$\mathrm{F}_{\mathrm{Ar}}$ is the molar flow-rate of Ar.

- The reactor thermo-chemical efficiency represents the fraction of solar energy that is converted and stored in a chemical form as hydrogen ${ }^{18}$ :

$\eta_{\mathrm{ch}}=\frac{\mathrm{F}_{0}, \mathrm{CH} 4 . \mathrm{X}_{\mathrm{CH} 4} \cdot \Delta H_{\text {Reactants(T0) } \rightarrow \text { Products(Treactor) }}}{P_{\text {solar }}}$

- The reactor thermal efficiency also takes into account the heating enthalpy of both the nonconverted reactants and the inert gas, it is expressed as: 


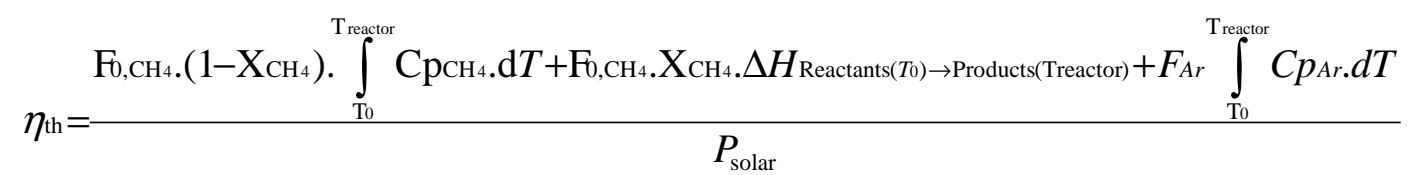

where $\Delta \mathrm{H}\left(\mathrm{J} \cdot \mathrm{mol}^{-1}\right)$ is the enthalpy change of the reaction (1) when the reactants are fed at $\mathrm{T}_{0}=298 \mathrm{~K}$ and the products are obtained at $\mathrm{T}_{\text {reactor }}, \mathrm{P}_{\text {solar }}$ is the solar power input $(\mathrm{W}), \mathrm{Cp}_{\mathrm{i}}$ is the specific heat of species i $\left(\mathrm{J} \cdot \mathrm{mol}^{-1} \cdot \mathrm{K}^{-1}\right.$, function of temperature).

This set of indicators is the foundation of the discussion below.

\section{1-Steady state, stability, reproducibility}

$\mathrm{CH}_{4}$ and $\mathrm{H}_{2}$ off-gas mole fractions given by the on-line analyzer are plotted in Fig. 3, along with the temperature measured by the pyrometer. Four consecutive experimental conditions are represented: the first run is carried out with $36 \mathrm{NL} / \mathrm{min}\left(6 \times 10^{-4} \mathrm{Nm}^{3} \mathrm{~s}^{-1}\right)$ of $\mathrm{Ar}$ and $8 \mathrm{NL} / \mathrm{min}\left(1.33 \times 10^{-4} \mathrm{Nm}^{3} \mathrm{~s}^{-1}\right)$ of $\mathrm{CH}_{4}$, the second run with $36 \mathrm{NL} / \mathrm{min}\left(6 \times 10^{-4} \mathrm{Nm}^{3} \mathrm{~s}^{-1}\right)$ of Ar and $12 \mathrm{NL} / \mathrm{min}\left(2 \times 10^{-4} \mathrm{Nm}^{3} \mathrm{~s}^{-1}\right)$ of $\mathrm{CH}_{4}$, the third run is identical to the first in order to test reproducibility, the last run is carried out with $28 \mathrm{NL} / \mathrm{min}$ $\left(4.67 \times 10^{-4} \mathrm{Nm}^{3} \mathrm{~s}^{-1}\right)$ of $\mathrm{Ar}$ and $8 \mathrm{NL} / \mathrm{min}\left(1.33 \times 10^{-4} \mathrm{Nm}^{3} \mathrm{~s}^{-1}\right)$ of $\mathrm{CH}_{4}$. 


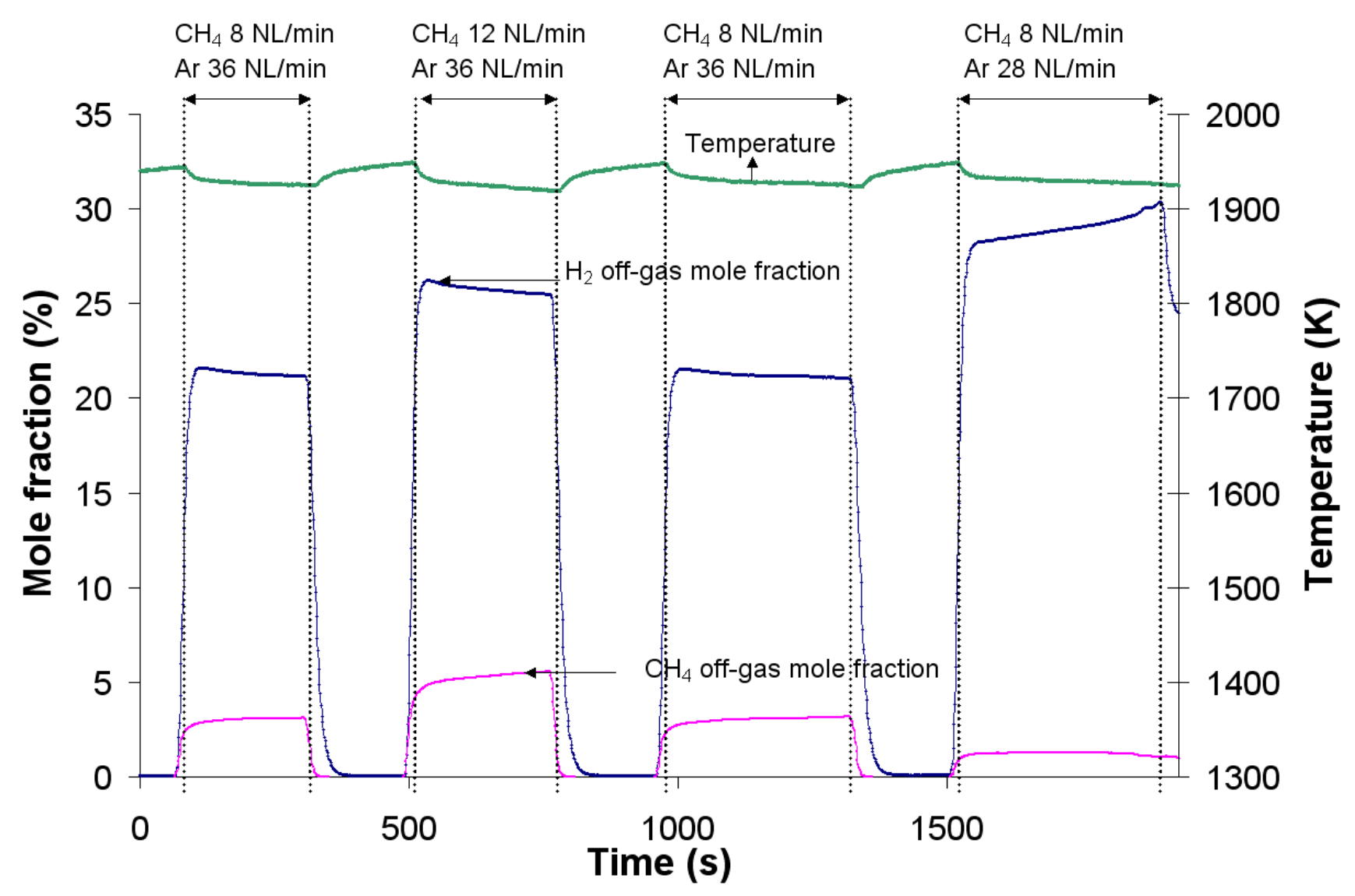

Figure 3. On-line $\mathrm{H}_{2}$ and $\mathrm{CH}_{4}$ off-gas mole fractions and temperature versus time for four consecutive runs

First, a plateau on the $\mathrm{H}_{2}$ off-gas mole fraction is obtained for the first three experimental conditions after about 1 to 2 minutes. It shows that steady state is rapidly reached. For the last experimental condition, this plateau is not observed even after 6 min. and the $\mathrm{H}_{2}$ mole fraction increases with time. This is due to a pressure increase in the reactor tubes as a result of tube blocking by carbon deposition. Consequently, the residence time increases and so does the $\mathrm{H}_{2}$ yield. The pressure can increase from 40 $\mathrm{kPa}$ to $100 \mathrm{kPa}$ in a few minutes, consequently the experiment is stopped.

Then, the first and third experimental runs prove that the same results are achieved for the same experimental conditions, both for $\mathrm{H}_{2}$ and $\mathrm{CH}_{4}$ off-gas concentrations (less than $1 \%$ difference on the $\mathrm{CH}_{4}$ conversion and $\mathrm{H}_{2}$ yield); and that there is no influence of the previous experimental conditions.

Finally, the temperature measurement shows fluctuations depending on the presence or absence of methane in the flow. As soon as methane is injected, the temperature decreases whereas it increases 
when stopping the methane flow (argon flow-rate is maintained). The variation is about 20-30 K. The decrease of temperature when $\mathrm{CH}_{4}$ is injected stems from the endothermic dissociation reaction. Thus, a slight reactor over-heating was set under argon flow before $\mathrm{CH}_{4}$ injection to anticipate the temperature decrease and to reach the given reaction temperature during experiments.

\section{2-Temperature influence}

A maximum working temperature of $2073 \mathrm{~K}$ has been achieved. In Fig. $4, \mathrm{CH}_{4}$ conversion and $\mathrm{C}_{2} \mathrm{H}_{2}$ mole fraction are plotted versus residence time for different temperatures $(1823 \mathrm{~K}, 1973 \mathrm{~K}$, and 2073 $\mathrm{K})$. The methane mole fraction in the inlet gas is kept constant at $20 \%$. The total gas flow-rate is changed, which thereby determines the gas residence time. The influence of temperature is clear: the higher the temperature, the higher the conversion for a given residence time. For a $11 \mathrm{~ms}$ residence time, $\mathrm{CH}_{4}$ conversion is $79 \%, 93 \%$, and $100 \%$ at $1823 \mathrm{~K}, 1973 \mathrm{~K}$, and $2073 \mathrm{~K}$, respectively. The methane conversion is total for temperatures higher than $1823 \mathrm{~K}$ and residence times longer than $25 \mathrm{~ms}$. Concerning $\mathrm{C}_{2} \mathrm{H}_{2}$ mole fraction in the off-gas, it seems to be more affected by residence time than by temperature. The lowest $\mathrm{C}_{2} \mathrm{H}_{2}$ concentrations are reached for the highest residence times. 


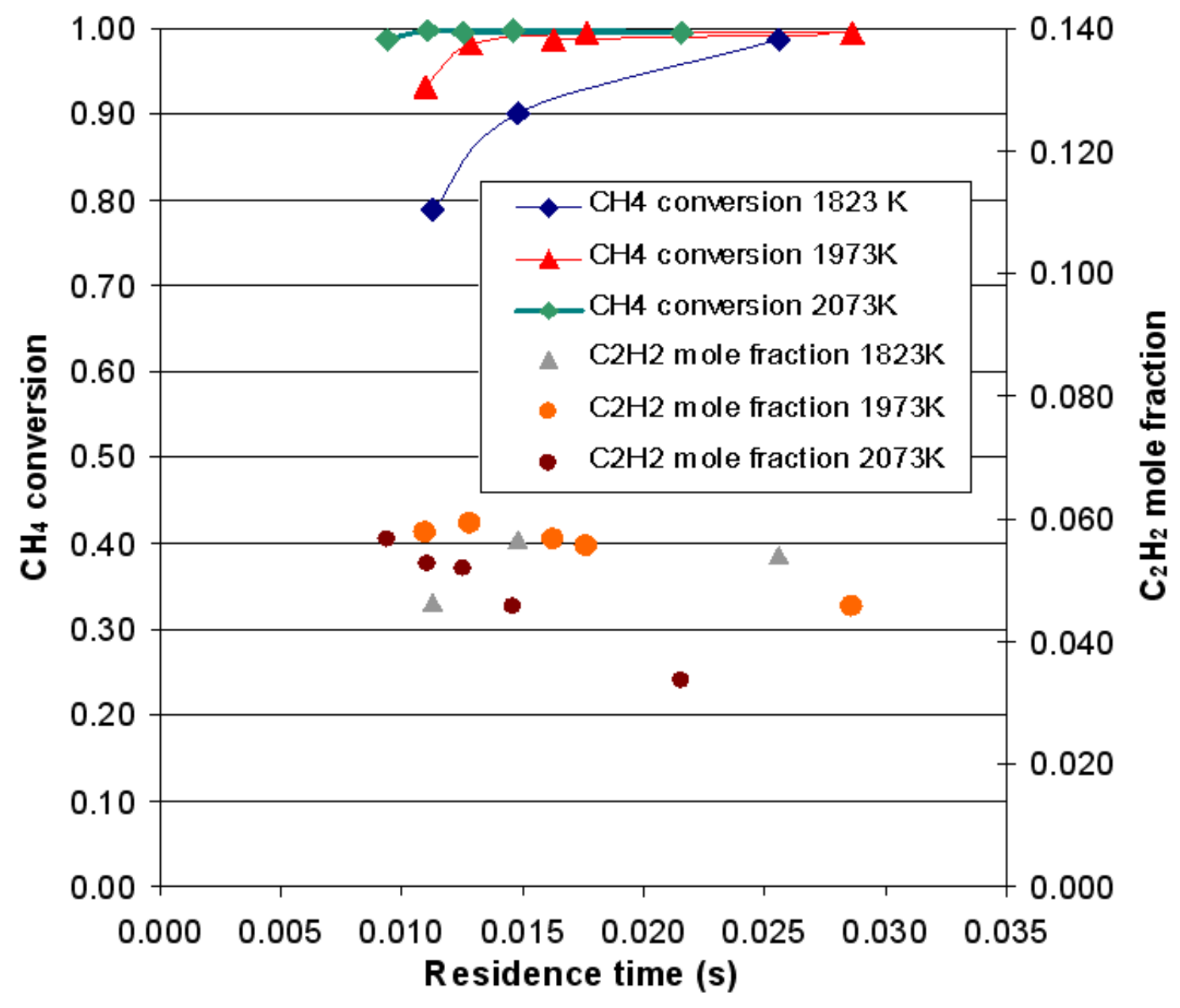

Figure 4. Temperature dependence of $\mathrm{CH}_{4}$ conversion and $\mathrm{C}_{2} \mathrm{H}_{2}$ off-gas mole fraction versus residence time $\left(\mathrm{CH}_{4}\right.$ mole fraction in the feed: $\left.20 \%\right)$

Assuming a first order kinetic expression ${ }^{16}$ and an ideal plug-flow reactor model, the residence time $\tau$ can be calculated from $^{19}$ :

$k \tau=-(1+\alpha) \beta \ln \left(1-X_{C H_{4}}\right)-\alpha \beta X_{C H 4}$

where $\alpha$ is the chemical expansion factor, $\beta$ is the physical dilatation factor, and $\mathrm{k}$ is the kinetic rate constant, following an Arrhenius law:

$\mathrm{k}=\mathrm{k} 0 . \exp \left(-\mathrm{E}_{\mathrm{a}} / R T\right)$ 
where $E_{a}$ denotes the activation energy $(\mathrm{J} / \mathrm{mol}), \mathrm{k}_{0}$ the pre-exponential factor $\left(\mathrm{s}^{-1}\right), \mathrm{R}$ the universal gas constant $(8.314 \mathrm{~J} / \mathrm{mol} \mathrm{K})$, and $\mathrm{T}$ the absolute temperature $(\mathrm{K})$.

Thus, it is possible to determine the kinetic rate $\mathrm{k}$ for different experimental temperatures. Data from previous reported results at lower temperatures ${ }^{21}$ are also included. Then, from the plot $\ln (\mathrm{k})=\mathrm{f}(1 / \mathrm{T}), \mathrm{a}$ linear regression $($ determination factor $=0.9982)$ allows estimating a pre-exponential factor of $1.42 \times 10^{7}$ $\mathrm{s}^{-1}$ and an activation energy of $172 \mathrm{~kJ} / \mathrm{mol}$. These values are consistent with previously reported activation energy for heterogeneous (catalytic) methane decomposition. The produced carbon black can play the role of catalyst ${ }^{11}$. This simplified model permits to estimate that the incertitude (for $\mathrm{T}=1823 \mathrm{~K}$ ) on $\mathrm{CH}_{4}$ conversion is $+/-1 \%$ for a temperature incertitude of $+/-10 \mathrm{~K}$ (that corresponds to the incertitude of experimental temperature measurements). Similarly, the incertitude on $\mathrm{CH}_{4}$ conversion is less than $+/-2 \%$ if the residence time is estimated at $+/-10 \%$. A variation of $+/-6 \%$ of the activation energy (estimated incertitude of the slope) also affects the $\mathrm{CH}_{4}$ conversion by $+/-17 \%$. Thus, uncertainties on the temperature or the residence time have a weak influence on the $\mathrm{CH}_{4}$ conversion, whereas the value of the activation energy is more critical and it just provides an order of magnitude of the kinetic parameters.

\section{3-Residence time influence}

The influence of residence time was studied at a given temperature for a constant $\mathrm{CH}_{4}$ mole fraction in the feed gas mixture (10\%). Residence times between $15 \mathrm{~ms}$ and $70 \mathrm{~ms}$ were tested at $1823 \mathrm{~K}$ (Fig. 5). For clarity reasons, $\mathrm{C}_{2} \mathrm{H}_{4}$ mole fraction is not represented because it was always below $400 \mathrm{ppm} . \mathrm{C}_{2} \mathrm{H}_{6}$ was not detected. 


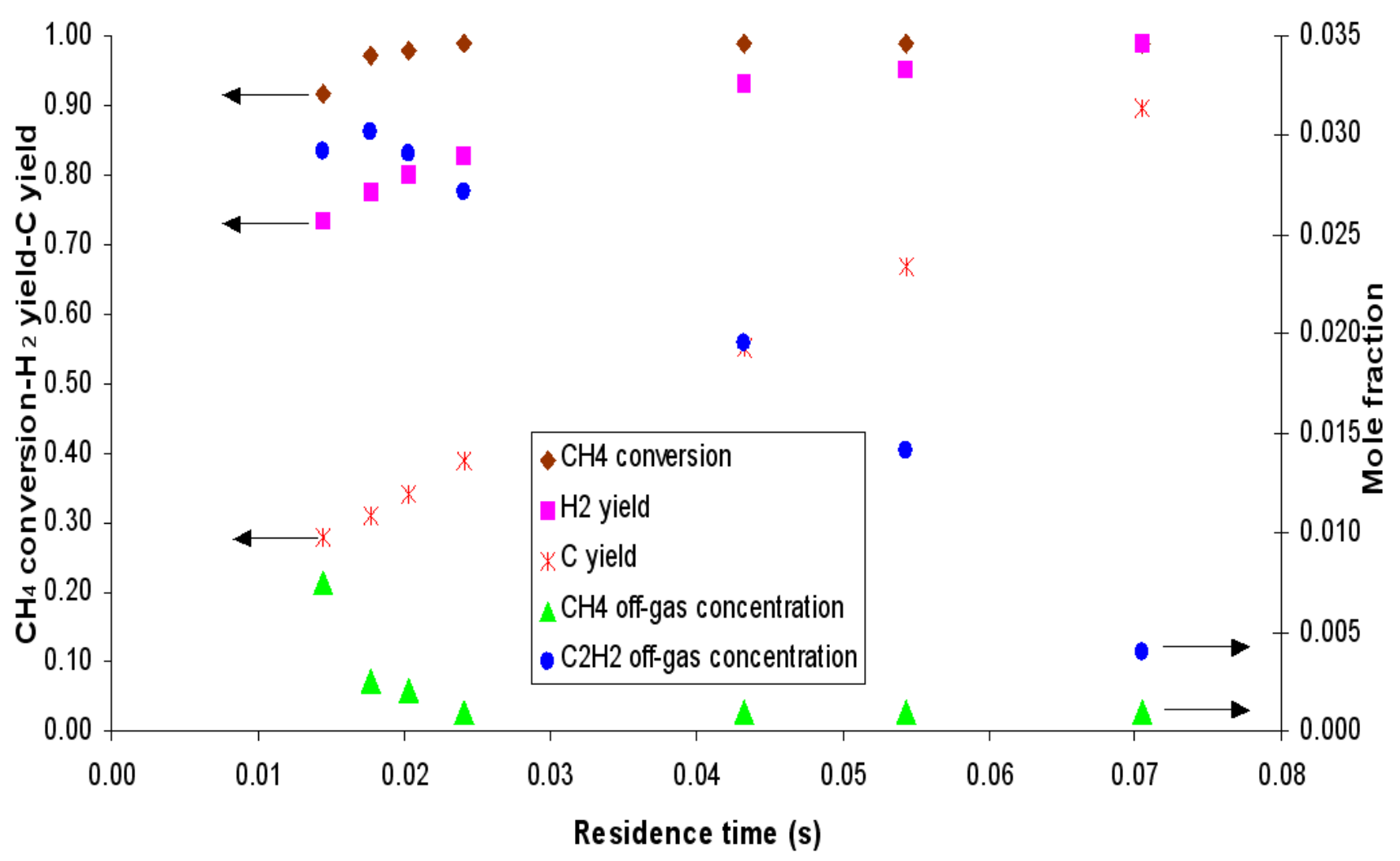

Figure 5. $\mathrm{CH}_{4}$ conversion, $\mathrm{H}_{2}$ yield, $\mathrm{C}$ yield, $\mathrm{CH}_{4}$ and $\mathrm{C}_{2} \mathrm{H}_{2}$ off-gas mole fractions versus residence time $\left(\mathrm{T}=1823 \mathrm{~K}, \mathrm{CH}_{4}\right.$ mole fraction in the feed: $\left.10 \%\right)$

In order to change the residence time, flow rates were modified. The first conclusion is that the $\mathrm{CH}_{4}$ conversion and the $\mathrm{H}_{2}$ yield are improved when increasing the residence time. A more in-depth analysis of the results also gives a scheme of the methane decomposition sequence. For residence times between $15 \mathrm{~ms}$ and $18 \mathrm{~ms}$, the $\mathrm{H}_{2}$ yield increases due to a better $\mathrm{CH}_{4}$ decomposition rate (off-gas concentration of $\mathrm{CH}_{4}$ decreases), while the off-gas concentration of $\mathrm{C}_{2} \mathrm{H}_{2}$ slightly increases. It means that methane is first converted into acetylene $\left(2 \mathrm{CH}_{4} \rightarrow \mathrm{C}_{2} \mathrm{H}_{2}+3 \mathrm{H}_{2}\right)$, thus releasing 1.5 mole of $\mathrm{H}_{2}$ per mole of $\mathrm{CH}_{4}$ converted. For longer residence times, the $\mathrm{H}_{2}$ yield is enhanced due to acetylene decomposition. Similar trends are observed in Fig. 4. For the lowest temperature $(1823 \mathrm{~K}), \mathrm{C}_{2} \mathrm{H}_{2}$ off-gas concentration presents a maximum whereas it decreases quite monotonically for higher temperatures because the maximum may occur at shorter residence times. This suggests that the rate of $\mathrm{C}_{2} \mathrm{H}_{2}$ formation becomes lower than the rate of $\mathrm{C}_{2} \mathrm{H}_{2}$ decomposition at any temperatures. Acetylene constitutes a reaction intermediate as 
reported previously ${ }^{24}$. Carbon yield is also represented and it can be observed that the decrease in the $\mathrm{C}_{2} \mathrm{H}_{2}$ off-gas concentration corresponds to an increase in carbon yield. $\mathrm{C}_{2} \mathrm{H}_{2}$ is thus converted into carbon black and $\mathrm{H}_{2}$. A residence time of $70 \mathrm{~ms}$ is needed in order to reach an off-gas $\mathrm{C}_{2} \mathrm{H}_{2}$ mole fraction lower than $0.5 \%$. A methane mole fraction of $50 \%$ in the feed gas mixture was also experimented at $1923 \mathrm{~K}$ for a residence time of $79 \mathrm{~ms}$, and the resulting off-gas $\mathrm{C}_{2} \mathrm{H}_{2}$ mole fraction was less than $300 \mathrm{ppm}$. With pure methane in the feed (without any argon flow), a residence time of $124 \mathrm{~ms}$ at $1923 \mathrm{~K}$ was reached and the off-gas $\mathrm{C}_{2} \mathrm{H}_{2}$ mole fraction was below $400 \mathrm{ppm}$. To increase hydrogen yield and avoid acetylene formation, long contact times are required, whereas very high temperatures are not favourable ${ }^{25}$.

Instead of speaking in terms of space time based on the inlet gas flow-rate $\left(\tau=\mathrm{V}_{\mathrm{r}} / \mathrm{Q}_{0}\right)$, it would be possible to calculate the mean residence time that takes into account the flow-rate at the exit of the reactor:

$\tau_{m}=\frac{V_{r}}{Q_{0} \beta\left(1+X_{C H 4} \alpha\right)}$

If the reference is taken at the entrance of the isothermal part of the reactor where the reaction occurs, then $\beta=1$. Thus, $\tau=1.10 . \tau_{\mathrm{m}}$ for a $10 \% \mathrm{CH}_{4}$ mole fraction in the feed $(\alpha=0.1)$ and $\mathrm{X}_{\mathrm{CH} 4}=1$. The "real" residence time (time required for an inert tracer to cross the reactor volume) is thus between the space time and the mean residence time. For sufficient dilution with argon, simulation results ${ }^{21}$ confirm that there is no significant difference between the "real" residence time and the space time. Obviously, the space time must be twice the mean residence time when complete dissociation is reached for pure methane. For this study on the influence of the residence time, a $\mathrm{CH}_{4}$ mole fraction of $10 \%$ is low enough to assimilate the space time to the real residence time.

\section{4-Influence of the $\mathrm{CH}_{4}$ mole fraction in the feed}


The influence of the methane concentration was investigated with a constant flow-rate of argon (18 $\left.\mathrm{NL} / \mathrm{min}, 3 \times 10^{-4} \mathrm{Nm}^{3} \mathrm{~s}^{-1}\right)$ and a methane flow-rate varying from $2 \mathrm{NL} / \mathrm{min}$ to $10 \mathrm{NL} / \mathrm{min}\left(3.33 \times 10^{-5}-\right.$ $1.67 \times 10^{-4} \mathrm{Nm}^{3} \mathrm{~s}^{-1}$ ), that is to say, a methane mole fraction in the feed varying from $10 \%$ to $36 \%$ (Fig. 6). The corresponding residence times, calculated at the actual tube temperature $(1923 \mathrm{~K})$ and pressure of each experimental condition, varies from $20 \mathrm{~ms}$ to $17 \mathrm{~ms}$. Thus, the residence is almost constant. Both $\mathrm{CH}_{4}$ conversion and $\mathrm{H}_{2}$ yield are plotted. The $\mathrm{CH}_{4}$ conversion is actually declining when increasing $\mathrm{CH}_{4}$ mole fraction in the feed. This may be due to the endothermic reaction. The $\mathrm{H}_{2}$ yield seems to dwindle sooner. Then, the higher the $\mathrm{CH}_{4}$ mole fraction in the feed gas, the higher the amount of $\mathrm{H}_{2}$ produced, but the lower the $\mathrm{CH}_{4}$ conversion. Nevertheless, 93\% $\mathrm{CH}_{4}$ conversion and $74 \% \mathrm{H}_{2}$ yield are still reached for a $\mathrm{CH}_{4}$ mole fraction of $36 \%$ in the feed. Consequently, increasing the $\mathrm{CH}_{4}$ mole fraction in the feed gas up to $36 \%$ allows enhancing the thermo-chemical efficiency, because a fairly good chemical conversion is maintained. An additional experimental run was also carried out at $1923 \mathrm{~K}$ for $100 \%$ methane in the feed. The dissociation was complete: the outlet $\mathrm{H}_{2}$ flow-rate was twice the inlet $\mathrm{CH}_{4}$ flow-rate. The residence time was $62 \mathrm{~ms}$ for $4 \mathrm{NL} / \mathrm{min}\left(6.67 \times 10^{-5} \mathrm{Nm}^{3} \mathrm{~s}^{-1}\right)$ of $\mathrm{CH}_{4}$ (mean residence time from Eq. 11 of $31 \mathrm{~ms})$. The quantity of by-products was negligible. Therefore, this run shows that reaction completion can be achieved with pure methane in the feed for a residence time much longer than the one used in Fig. 6. Nevertheless, one must point out that the long residence time due to the low gas velocity caused a substantial carbon deposit in the tubes. Even if increasing the mole fraction improves the efficiency of the reactor, high methane concentrations along with high residence times favor carbon deposition. 


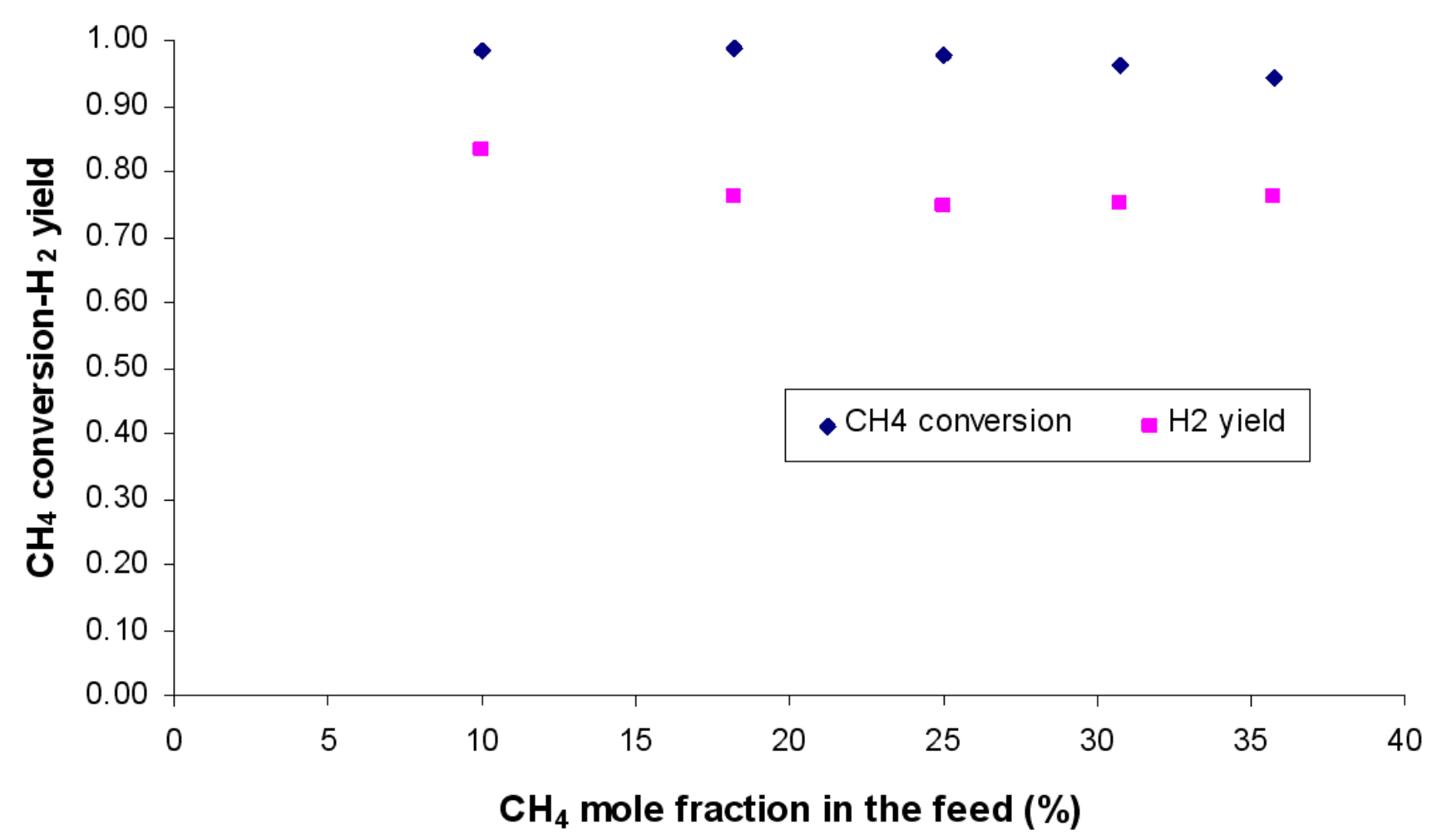

Figure 6. $\mathrm{CH}_{4}$ conversion and $\mathrm{H}_{2}$ yield versus $\mathrm{CH}_{4}$ mole fraction in the feed at $1923 \mathrm{~K}$

\section{5-Methane cracking versus natural gas cracking}

Natural gas was introduced instead of methane to examine the effect of feedstock composition. A chromatography analysis of this natural gas highlights the presence of about $9.5 \%$ ethane and trace amounts of $\mathrm{CO}_{2}$ and $\mathrm{N}_{2}$. Fig. 7 plots the mole fractions of $\mathrm{H}_{2}, \mathrm{C}_{2} \mathrm{H}_{2}$, and $\mathrm{CH}_{4}$ as a function of residence time for methane cracking and natural gas cracking experiments at $1873 \mathrm{~K}$. The comparison shows a small discrepancy limited to a few percents, which is in the range of experimental uncertainties. As predicted by the Dsmoke kinetic software ${ }^{21}$, there is no difference between natural gas cracking and pure methane cracking for a residence time higher than $1 \mathrm{~ms}$. The only difference is expected for shorter residence times due to the presence of ethane $\left(\mathrm{C}_{2} \mathrm{H}_{6}\right)$ that is easier to decompose than $\mathrm{CH}_{4}$. 


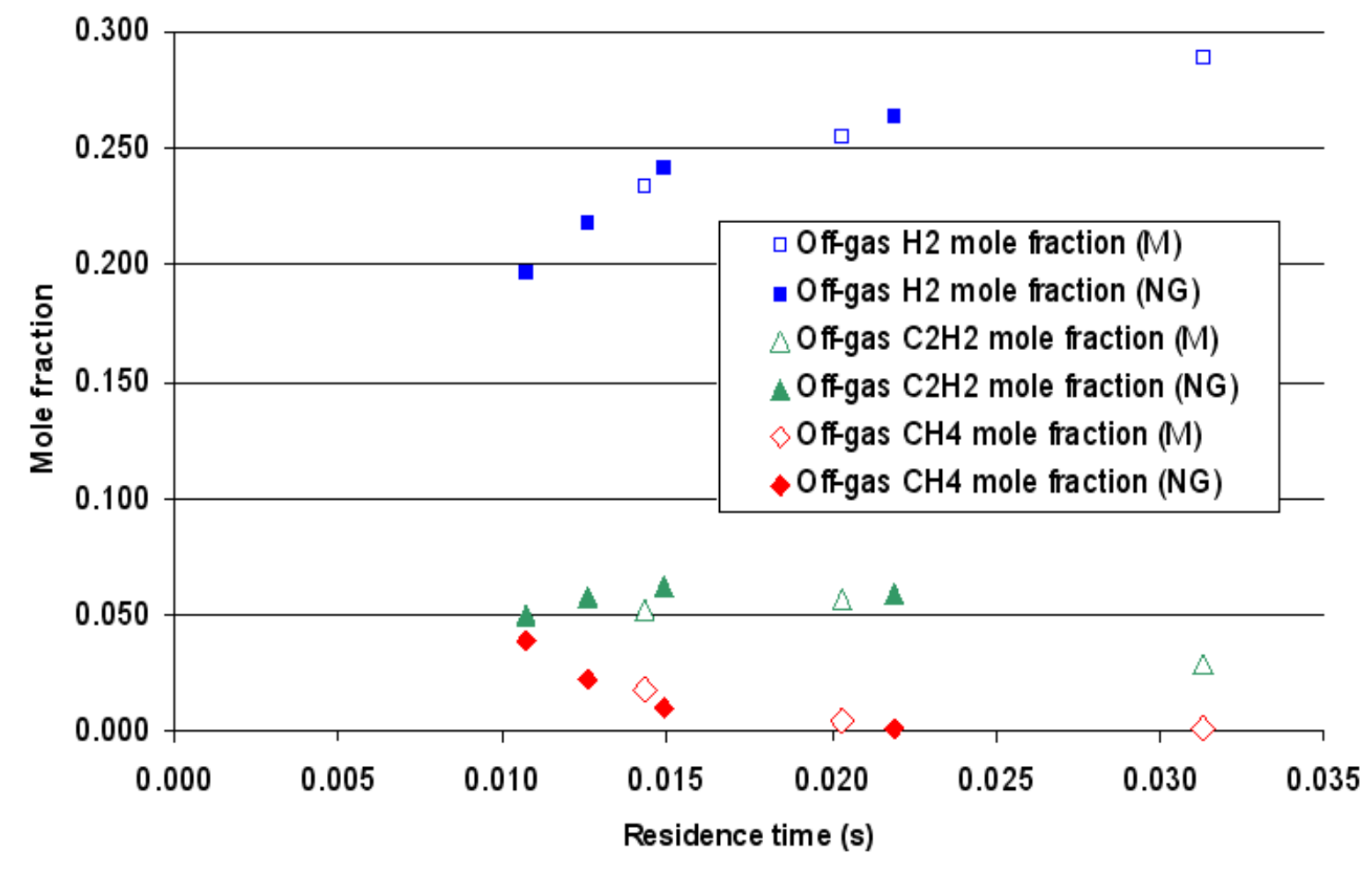

Figure 7. Off-gas $\mathrm{H}_{2}, \mathrm{C}_{2} \mathrm{H}_{2}$, and $\mathrm{CH}_{4}$ mole fractions for methane cracking (M) and natural gas cracking $(\mathrm{NG})(\mathrm{T}=1873 \mathrm{~K})$

\section{6-Carbon and hydrogen mass balances}

A mass balance was established based on a series of 5 experimental runs at $1923 \mathrm{~K}$ with a constant argon flow-rate of $18 \mathrm{NL} / \mathrm{min}\left(3 \times 10^{-4} \mathrm{Nm}^{3} \mathrm{~s}^{-1}\right)$ and a methane flow-rate varying from $2 \mathrm{NL} / \mathrm{min}$ to 10 $\mathrm{NL} / \min \left(3.33 \times 10^{-5}-1.67 \times 10^{-4} \mathrm{Nm}^{3} \mathrm{~s}^{-1}\right)$. Fig. 8 plots the off-gas mole fractions of $\mathrm{H}_{2}, \mathrm{CH}_{4}$, and $\mathrm{C}_{2} \mathrm{H}_{2}$ throughout the experiment. The mass balances are obtained by integrating these data. 


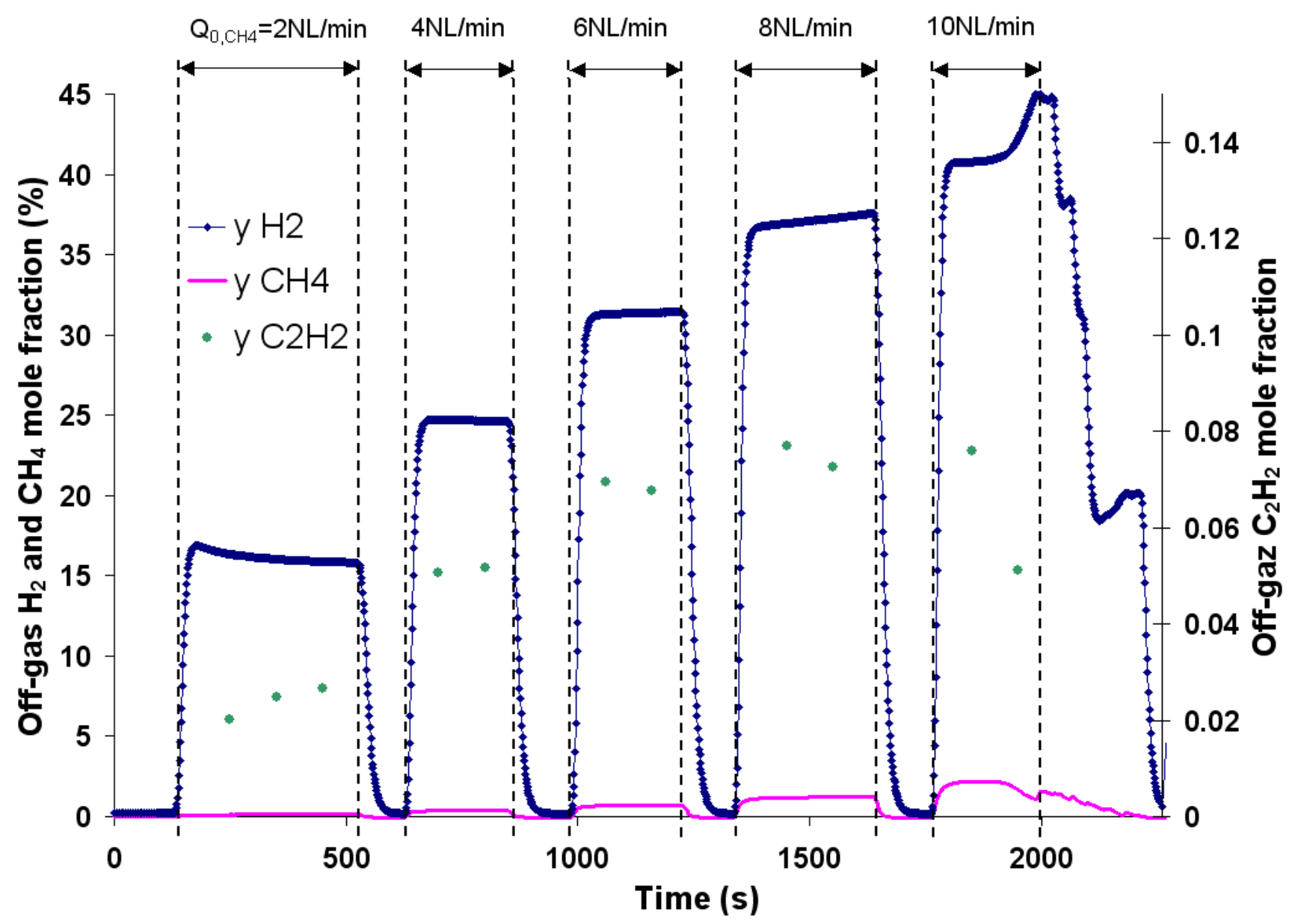

Figure 8. $\mathrm{H}_{2}, \mathrm{CH}_{4}$, and $\mathrm{C}_{2} \mathrm{H}_{2}$ mole fractions in the off-gas versus time ( $\mathrm{T}=1923 \mathrm{~K}$, Ar flow-rate: 18 $\mathrm{NL} / \mathrm{min})$

The reactor tubes and the filter were weighted before and after experiments. The mass of carbon accumulated in the tubes was $26.4 \mathrm{~g}$, while $1.5 \mathrm{~g}$ of carbon was recovered in the filter. A total of 146.5 NL $\left(0.1465 \mathrm{Nm}^{3}\right)$ of methane was introduced in the reactor. Then, a mass balance between the recovered solid carbon and the amounts of gaseous species in the off-gas shows that $93 \%$ of the initial carbon mass and $92 \%$ of the initial hydrogen mass are retrieved at the exit according to the following calculations (only $\mathrm{H}_{2}, \mathrm{C}, \mathrm{CH}_{4}$, and $\mathrm{C}_{2} \mathrm{H}_{2}$ are taken into account, the other hydrocarbons are neglected):

$$
C(\text { ratio })=\frac{\frac{m_{C H 4}}{M_{C H 4}}+\frac{2 m_{C 2 H 2}}{M_{C 2 H 2}}+\frac{m_{C}}{M_{C}}}{\frac{m_{0, \mathrm{CH} 4}}{M_{0, \mathrm{CH} 4}}}
$$




$$
H(\text { ratio })=\frac{\frac{4 m_{C H 4}}{M_{C H 4}}+\frac{2 m_{C 2 H 2}}{M_{C 2 H 2}}+\frac{2 m_{H 2}}{M_{H 2}}}{\frac{4 m_{0, C H 4}}{M_{0, C H 4}}}
$$

Fig. 9 shows the $\mathrm{H}$ mass balance. $75 \%$ of $\mathrm{H}$ atoms is found as $\mathrm{H}_{2}$ gas, $14 \%$ is in the form of $\mathrm{C}_{2} \mathrm{H}_{2}, 3 \%$ is contained in the unconverted $\mathrm{CH}_{4}$, and the remaining $8 \%$ is thus attributed to other hydrocarbons. A fraction of the missing $\mathrm{H}$-content may also be found in the carbon black although the $\mathrm{H}$-content in the channel black (that presents the largest amount of hydrogen) is less than $1 \%$ (molar) ${ }^{3}$.According to this balance, $\mathrm{CH}_{4}$ is efficiently converted into $\mathrm{H}_{2}\left(75 \% \mathrm{H}_{2}\right.$ yield $)$.

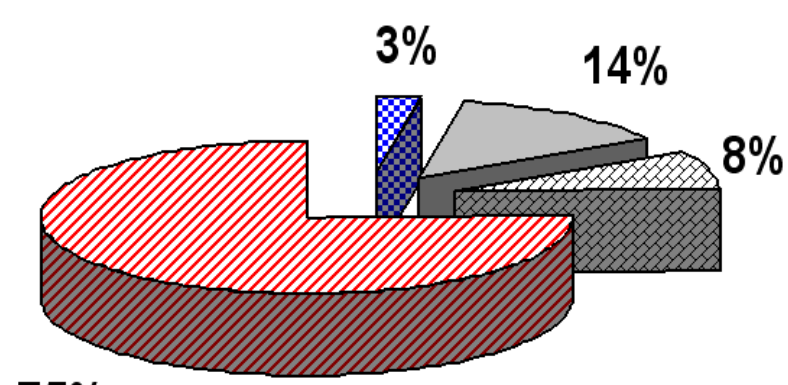

$75 \%$
冈 Hydrogen in CH4

$\square$ Hydrogen in $\mathrm{C} 2 \mathrm{H} 2$

图 Hydrogen in other HC

Pure hydrogen

Figure 9. Typical H balance ( $\mathrm{T}=1923 \mathrm{~K}$, Ar flow-rate: $18 \mathrm{NL} / \mathrm{min}$ )

Fig. 10 shows the $\mathrm{C}$ mass balance. $54 \%$ of the carbon is contained in $\mathrm{C}_{2} \mathrm{H}_{2}$. Only $36 \%$ of the carbon is recovered as solid carbon either in the reactor tubes (34\%) or in the filter (2\%). $3 \%$ of carbon stays in the unconverted $\mathrm{CH}_{4}$. The remaining part $(7 \%)$ may be contained in other hydrocarbons or may correspond to un-removed solid carbon. Methane is not as well converted into solid carbon as it is in $\mathrm{H}_{2}$ due to the substantial presence of $\mathrm{C}_{2} \mathrm{H}_{2}$. 


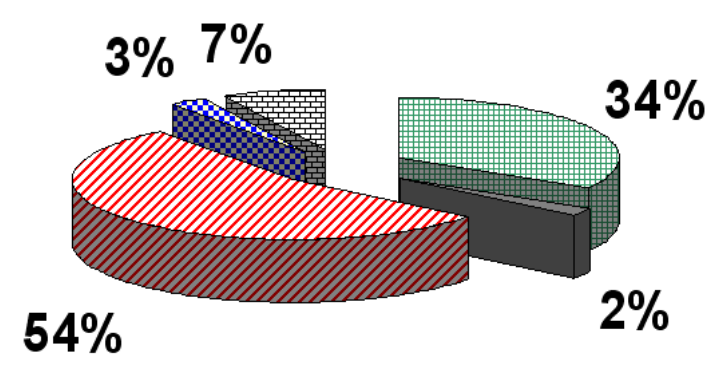

$\square$ Carbon in the filter

Carbon in $\mathrm{C} 2 \mathrm{H} 2$

Carbon in the remaining $\mathrm{CH} 4$

罯 Carbon missing (un removed

deposit, other hydrocarbons...)

Figure 10. Typical C balance ( $\mathrm{T}=1923 \mathrm{~K}$, Ar flow-rate: $18 \mathrm{NL} / \mathrm{min}$ )

\section{7- Efficiency of the reactor}

Owing to the production of by-products, the thermo-chemical efficiency as defined previously in Eq.

(7) is not perfectly suitable. Indeed, it only gives the real efficiency of the reactor if the dissociation was complete, otherwise it is under-estimated. According to previous kinetic analyses of the reaction with a detailed chemical mechanism model, $\mathrm{C}_{2} \mathrm{H}_{6}$ and $\mathrm{C}_{2} \mathrm{H}_{4}$ are rapidly decomposed, and $\mathrm{C}_{2} \mathrm{H}_{2}$ is the only byproduct present in appreciable amount at the exit of the reactor ${ }^{21}$, which is consistent with the gas analysis results. Thus, a two-step dissociation scheme is proposed according to the experimental results:

$$
\mathrm{CH}_{4} \rightarrow 3 / 2 \mathrm{H}_{2}+1 / 2 \mathrm{C}_{2} \mathrm{H}_{2} \quad \text { endothermal, } \Delta \mathrm{H}_{1}{ }^{\circ}=188 \mathrm{~kJ} \mathrm{~mol}^{-1}
$$

$$
\mathrm{C}_{2} \mathrm{H}_{2} \rightarrow \mathrm{H}_{2}+2 \mathrm{C} \quad \text { exothermal, } \Delta \mathrm{H}_{2}{ }^{\circ}=-227 \mathrm{~kJ} \mathrm{~mol}^{-1}
$$

The standard enthalpy of methane-to-acetylene formation (Eq. 14) is more than twice the standard enthalpy of single-step methane dissociation (Eq. 1). In addition, a part of acetylene formed from methane is not dissociated into hydrogen, as shown by the analysis of the exhaust gas stream. This intermediate step involving acetylene must be taken into account in the calculation of the reactor 
efficiency. The fractional conversions of the successive reactions (14) and (15) are the solutions of the following system:

$$
\begin{aligned}
& F_{\mathrm{H}_{2}}=(1 / 2 \cdot X \cdot Y+3 / 2 \cdot X) \cdot F_{0, \mathrm{CH}_{4}} \\
& F_{\mathrm{C}_{2} \mathrm{H}_{2}}=(1-Y) 1 / 2 \cdot X \cdot F_{0, \mathrm{CH}_{4}}
\end{aligned}
$$

where $\mathrm{Y}$ is the fractional conversion of reaction (15) defined as $\mathrm{Y}=\mathrm{F}_{\mathrm{H} 2} / \mathrm{F}_{0, \mathrm{C} 2 \mathrm{H} 2}$ where $\mathrm{F}_{0, \mathrm{C} 2 \mathrm{H} 2}$ is the molar flow-rate of acetylene issued from reaction (14). The fractional conversion X of reaction (14) should be equal to the $\mathrm{CH}_{4}$ conversion $\mathrm{X}_{\mathrm{CH} 4}$ defined in Eq. (3) if the real chemical mechanism was only composed of reactions (14) and (15). Nevertheless, this assumption is not exactly satisfied since $\mathrm{X}$ is always smaller (about $6 \%$ ) than $\mathrm{X}_{\mathrm{CH} 4}$. This proves that the chemical mechanism includes additional steps and intermediates ${ }^{26-28}$. However, this two-step reaction model can fairly describe the production of the three major species $\left(\mathrm{C}, \mathrm{C}_{2} \mathrm{H}_{2}\right.$, and $\left.\mathrm{H}_{2}\right)$ in a simple realistic way. Then, a more accurate expression of the thermo-chemical efficiency can be written as:

$$
\eta_{\text {ch, new }}=\frac{\mathrm{F}_{0}, \mathrm{CH}_{4} . X \cdot \int_{\mathrm{T}_{0}}^{\mathrm{T}_{\text {reactor }}} C p_{C H}{ }_{4} \mathrm{dT}+\mathrm{F}_{0}, \mathrm{CH} 4 . X . \Delta H_{1}\left(\mathrm{~T}_{\text {reactor }}\right)+1 / 2 . \mathrm{F}_{0}, \mathrm{CH} 4 . X . Y . \Delta H_{2}\left(\mathrm{~T}_{\text {reactor }}\right)}{P_{\text {solar }}}
$$

and the thermal efficiency becomes:

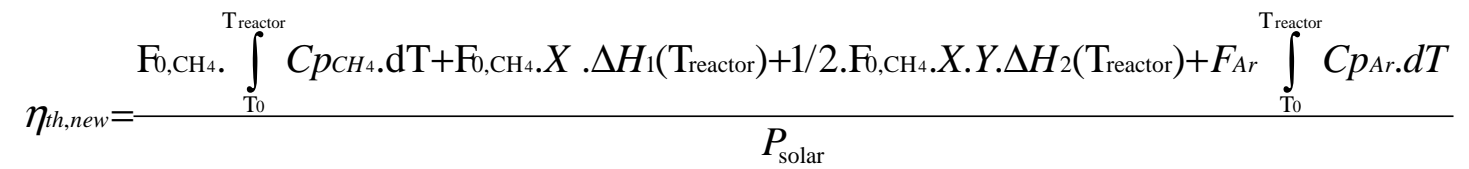

For each run, the solar power is calculated from calorimetric measurements at the center of the reactor aperture. As a first approximation, the solar flux density is assumed homogeneous at the aperture, which may lead to a slightly over-estimated solar power. The net solar power absorbed varies between $16.9 \mathrm{~kW}$ and $25.8 \mathrm{~kW}$ depending on the working temperature between $1823 \mathrm{~K}$ and $2073 \mathrm{~K}$. Fig. 11 illustrates the evolution of the above defined efficiencies at $1823 \mathrm{~K}, 1873 \mathrm{~K}, 1973 \mathrm{~K}$, and $2073 \mathrm{~K}$. For each temperature, the $\mathrm{CH}_{4}$ mole fraction in the feed was $20 \%$. Obviously, the thermo-chemical efficiency (Eq. 18) is always lower than the thermal efficiency (Eq. 19). The calculated reactor thermo-chemical efficiencies are improved when accounting for the presence of acetylene as a high energy value by- 
product. In contrast, $\mathrm{C}_{2} \mathrm{H}_{2}$ formation lowers the power available for methane dissociation. Indeed, the amount of energy consumed per mole of converted methane is higher in the two-step endothermal and exothermal reaction scheme $\left(\Delta \mathrm{H}_{1}+1 / 2\right.$. Y. $\left.\Delta \mathrm{H}_{2}\right)$ than in the single-step $\mathrm{CH}_{4}$ dissociation $\left(\Delta \mathrm{H}_{1}+1 / 2 . \Delta \mathrm{H}_{2}\right)$. Thus, the fraction of solar energy devoted to reaction enthalpy is strengthened when $\mathrm{C}_{2} \mathrm{H}_{2}$ intermediate is considered in the calculation.

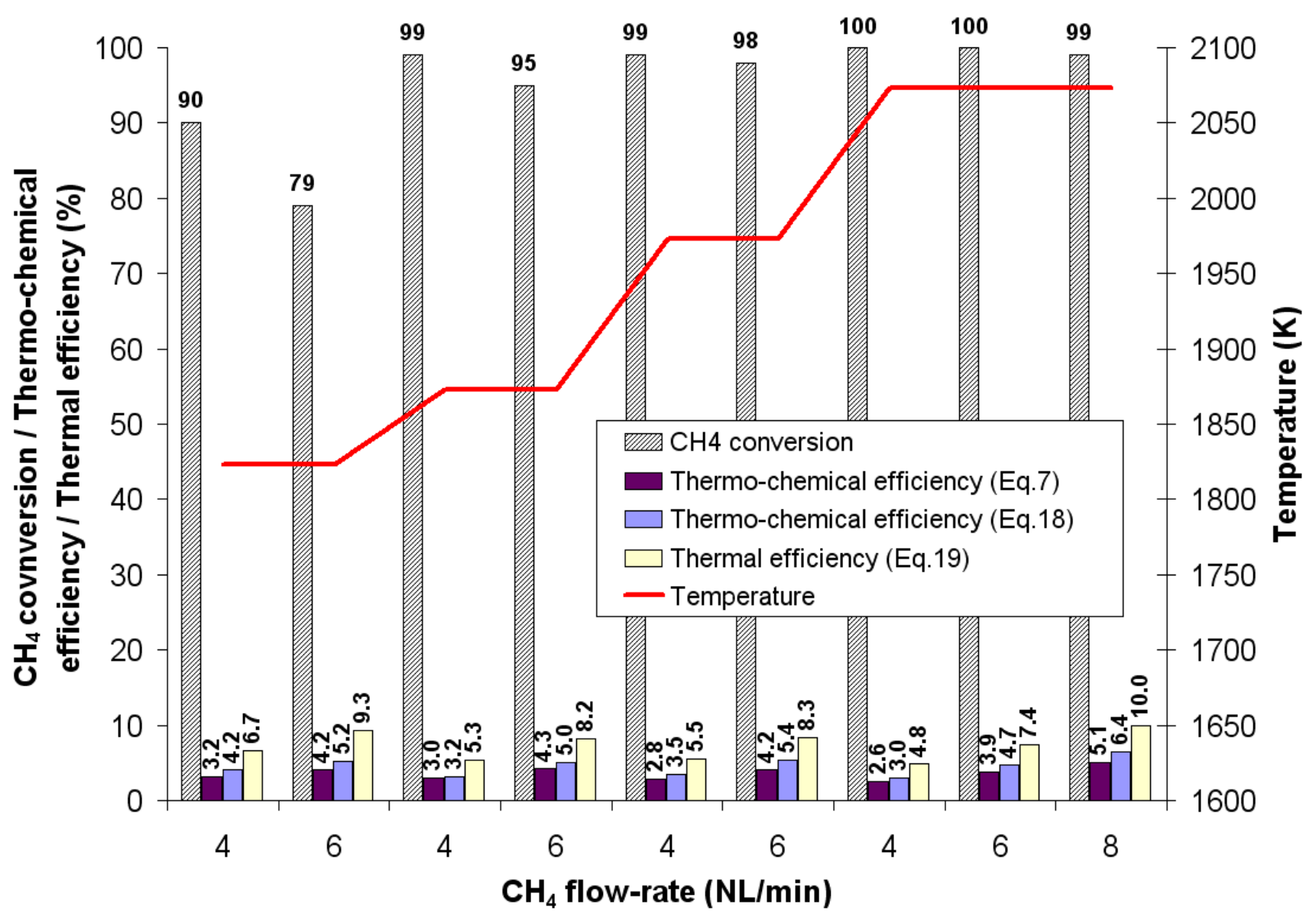

Figure 11. $\mathrm{CH}_{4}$ conversion and reactor efficiencies (for a single-step reaction model or a two-step mechanism) as a function of temperature and $\mathrm{CH}_{4}$ flow-rate $\left(\mathrm{CH}_{4}\right.$ mole fraction in the feed: $\left.20 \%\right)$

For a given temperature, an increase in $\mathrm{CH}_{4}$ flow-rate results in significant efficiencies improvement (both thermo-chemical and thermal), but in counterpart it affects the $\mathrm{CH}_{4}$ conversion, especially at low temperature. At $1823 \mathrm{~K}, \mathrm{CH}_{4}$ conversion is only $79 \%$ for $6 \mathrm{NL} / \mathrm{min}\left(1 \times 10^{-4} \mathrm{Nm}^{3} \mathrm{~s}^{-1}\right)$ of fed $\mathrm{CH}_{4}$, whereas $\mathrm{CH}_{4}$ conversion is almost complete at higher temperatures. On the basis of the reported reactor 
efficiencies, an optimum temperature for reactor operation may exist. Indeed, $\mathrm{CH}_{4}$ conversion exceeds 95\% for temperatures higher than $1873 \mathrm{~K}$, while thermal efficiencies tend to decrease when increasing the temperature $\left(9.3 \%\right.$ at $1823 \mathrm{~K}$ and $7.4 \%$ at $2073 \mathrm{~K}$ for $6 \mathrm{NL} / \mathrm{min}\left(1 \times 10^{-4} \mathrm{Nm}^{3} \mathrm{~s}^{-1}\right)$ of $\left.\mathrm{CH}_{4}\right)$. This is due to the increased solar power input when raising the temperature, and to more induced radiation losses. In order to maximize both the $\mathrm{CH}_{4}$ conversion and the thermal efficiency of the reactor, a temperature between $1873 \mathrm{~K}$ and $1973 \mathrm{~K}$ is advised, the smallest being preferable for coupling the process with existing solar concentrating technologies. The optimum temperature range has been identified on the basis of optimized reaction efficiencies. Further work is required to optimize as well the solar concentrating systems and the carbon black properties that are both key issues for the process economics. A $50 \mathrm{~kW}$ pilot-scale solar reactor is under construction to produce larger quantities of carbon black and to determine its properties. The main heat losses in the current solar reactor were identified to be infrared radiation emission through the window and conduction through the watercooled front face. For increasing reactor efficiencies, the front face insulation should be improved and a higher solar concentration ratio is required to minimize IR-radiation losses.

\section{4-Conclusion}

Solar thermal dissociation of methane was investigated in a multi-tubular solar reactor prototype operating in the high temperature range $1823 \mathrm{~K}-2073 \mathrm{~K}$. A wide range of experimental conditions was tested: methane flow rate up to $12 \mathrm{NL} / \mathrm{min}\left(2 \times 10^{-4} \mathrm{Nm}^{3} \mathrm{~s}^{-1}\right), \mathrm{CH}_{4}$ mole fraction in the feed up to $100 \%$, and residence time from $10 \mathrm{~ms}$ and beyond $100 \mathrm{~ms}$. $\mathrm{CH}_{4}$ conversion chiefly increased with temperature and residence time, whereas $\mathrm{C}_{2} \mathrm{H}_{2}$ content in the off-gas was more lowered when raising the residence time than the temperature. $\mathrm{C}$ and $\mathrm{H}$ mass balances showed that $\mathrm{C}_{2} \mathrm{H}_{2}$ formation strongly alleviates the $\mathrm{C}$ yield. Moreover, a two-step reaction mechanism was proposed involving $\mathrm{C}_{2} \mathrm{H}_{2}$ intermediate. The highly endothermic $\mathrm{C}_{2} \mathrm{H}_{2}$ formation lowers the power available for methane dissociation. Both thermal and thermo-chemical efficiencies are improved when increasing the methane flow-rate in the feed. The 
lower the temperature, the longer the required residence time for reducing $\mathrm{C}_{2} \mathrm{H}_{2}$ formation. A temperature of about $1873 \mathrm{~K}$ is advised to optimize both the methane conversion and the reactor thermal efficiency. A test with a different feedstock composition (natural gas instead of methane) did not modify the reactor performances.

A $50 \mathrm{~kW}$ pilot solar reactor is currently under construction to investigate the process at a larger scale, and to characterize the properties of the solar-produced carbon black with respect to the commercial standards.

\section{Acknowledgements:}

This work was financially supported by the European Project Solhycarb (2006-2010, Contract SESCT2006-19770). Authors thank Jean-Louis Sans, Olivier Prévost, Marc Garrabos and Emmanuel Guillot for their technical support during the solar reactor manufacturing and the experimental campaigns at the 1 MW solar furnace of CNRS-PROMES (France).

\section{Nomenclature:}

$\mathrm{C}_{\mathrm{pi}} \quad$ specific heat of species $\mathrm{i}(\mathrm{J} / \mathrm{mol} . \mathrm{K}$, function of temperature)

$\mathrm{E}_{\mathrm{a}} \quad$ activation energy $(\mathrm{J} / \mathrm{mol})$

F total molar flow-rate $(\mathrm{mol} / \mathrm{s})$

$\mathrm{F}_{\mathrm{i}} \quad$ molar flow-rate of species i (mol/s)

$\mathrm{F}_{0, \mathrm{i}} \quad$ inlet molar flow-rate of species i (mol/s)

$\Delta \mathrm{H}^{\circ}$ standard reaction enthalpy $(\mathrm{J} / \mathrm{mol})$

$\mathrm{k}_{0} \quad$ pre-exponential factor $\left(\mathrm{s}^{-1}\right)$

$\mathrm{m}_{\mathrm{i}} \quad$ mass of species $\mathrm{i}(\mathrm{kg})$

$\mathrm{M}_{\mathrm{i}} \quad$ molecular weight of species $\mathrm{i}(\mathrm{kg} / \mathrm{mol})$

NL Normal Liter (at normal conditions: $101.325 \mathrm{kPa}$ and 273.15 K) 
$\mathrm{P} \quad$ absolute pressure $(\mathrm{Pa})$

$\mathrm{P}_{\text {solar }}$ solar power input $(\mathrm{W})$

$\mathrm{Q}_{0} \quad$ volumetric inlet flow-rate of argon and methane at the actual tube temperature and pressure $\left(\mathrm{m}^{3} / \mathrm{s}\right)$

R universal gas constant $(8.314 \mathrm{~J} / \mathrm{mol} \mathrm{K})$

$\mathrm{T}$ absolute temperature $(\mathrm{K})$

$\mathrm{T}_{0} \quad$ reference temperature $(298 \mathrm{~K})$

$V_{r} \quad$ volume of the isothermal part of the tubes where the reaction occurs $\left(\mathrm{m}^{3}\right)$

$\mathrm{X}_{\mathrm{CH} 4} \quad$ methane conversion

Yc carbon yield

$\mathrm{Y}_{2}$ hydrogen yield

$\mathrm{y}_{\mathrm{i}} \quad$ mole fraction of species $\mathrm{i}$

Greek letters

$\tau \quad$ space time (s)

$\tau_{\mathrm{m}} \quad$ mean residence time (s) 


\section{References:}

(1) DOE (Department of Energy). A multi-year plan for the hydrogen R\&D program. Rationale, structure and technology roadmaps. Office of Power Delivery and Office of Power Technologies, 1999.

(2) Dahl, J.K.; Buechler, K.J.; Finley, R.; Stanislaus, T.; Weimer, A.W.; Lewandowski, A.; Bingham, C.; Smeets, A.; Schneider, A. Energy 2004, 29(5-6), 715-725.

(3) Donnet, J.B.; Bansal, R.C.; Wang, M.J.; Carbon Black, Second Edition, New York: Marcel Dekker, 1993.

(4) Wyss, J.; Martinek, J.; Kerins, M.; Dahl, J.K.; Weimer, A.; Lewandowski, A.; Bingham C. Int. J. Chem. Reactor Eng. 2007, 5(A69).

(5) Hirsch, D.; Epstein, M.; Steinfeld, A. Int. J. Hydrogen Energy 2001, 26(10), 1023-1033.

(6) Holmen, A.; Olsvik, O.; Rokstad, O.A. Fuel Process. Technol. 1995, 42(2-3), 249-267.

(7) Back, M.H.; Back, R.A. Pyrolysis: theory and industrial practice; New York: Academic Press, 1983, $1-24$.

(8) Jr. Gardiner, W.C.; Owen, J.H.; Clark, T.C.; Dove, J.E.; Bauer, S.H.; Miller, J.A.; McLean, W.J. Syp. (Int.) Combust. 1974, 15, 957.

(9) Chen, C.J.; Back, M.H.; Back R.A. Can. J. Chem. 1975, 53, 3580-3590.

(10) Lee, K.L.; Lee, S.Y.; Han G.Y., Lee B.K., Lee T.J., Jun J.H., Yoon K.J. Carbon 2004, 42, 2641 2648.

(11) Muradov, N.; Smith, F.; T-Raissi, A. Catal. Today 2005, 102, 225-233.

(12) Lédé, J.; Weber, C.; Villermaux, J. Academie des Sciences (Paris), Comptes Rendus, Serie B Sciences Physiques 1978, 286(22), 299-302.

(13) Billaud, F.; Baronnet, F.; Freund, E.; Busson, C.; Weill, J. Rev. Inst. Fr. Pét. 1989, 44(6), 813-823. 
(14) Steinfeld, A.; Kirillov, V.; Kuvshinov, G., Mogilnykh Y.; Reller, Chem. Eng. Sci. 1997, 52(20), 3599-3603.

(15) Kogan, M.; Kogan, A. Int. J. Hydrogen Energy 2003, 28(11), 1187-1198.

(16) Trommer, D.; Hirsch, D.; Steinfeld, A. Int. J. Hydrogen Energy 2004, 29(6), 627-633.

(17) Kogan, A.; Kogan, M.; Barak, S. Int. J. Hydrogen Energy 2004, 29(12), 1227-1236.

(18) Hirsch, D.; Steinfeld, A. Int. J. Hydrogen Energy 2004, 29(1), 47-55.

(19) Abanades, S.; Flamant, G. Chem. Eng. Process.: Process Intensif. 2008, 47(3), 490-498.

(20) Dahl, J.K.; Buechler, K.J.; Weimer, A.W.; Lewandowski, A.; Bingham, C. Int. J. Hydrogen Energy 2004, 29(7), 725-736.

(21) Rodat, S.; Abanades, S.; Coulié, J.; Flamant, G. Chem. Eng. J., 2009, 146(1), 120-127.

(22) Abanades, S., Flamant, G. Chem. Eng. Commun 2008., 195(9), 1159-1175.

(23) Bruce Nauman, E. Ind. Eng. Chem. Res. 2008, 47, 3752-3766.

(24) Happel, J.; Kramer, L. Ind. Eng. Chem. 1967, 59(1), 39-71.

(25) Choudhary, T.V.; Aksoylu, E.; Goodman, D.W. Catal. Rev. 2003, 45(1), 151-203.

(26) Olsvik, O; Rokstad, O.A.; Holmen; A. Chem. Eng. Technol. 1995, 18, 349-58.

(27) Billaud, F.; Guéret, G.; Weill, J. Thermochim Acta 1992, 211, 303-322.

(28) Fincke, J.R.; Anderson, R.P.; Hyde, T.A.; Detering, B.A. Ind. Eng. Chem. Res. 2002, 41(6), 14251435. 